\title{
Evaluation Methods about Emulsifying Properties of Surfactants used in Cosmetics
}

\author{
Shigeharu Tanizawa, Kenji Sato and Shoji Yuasa
}

\begin{abstract}
Some evaluation methods about emulsifying properties of surfactants in combination with typical oils used in cosmetics, cloud point in oil saturation, phase inversion temperature, emulsifying power and emulsion stability are mentioned,

The combination effect of representative surfactants with oils in emulsifying properties is discussed by each evaluation method. Especially the branching alkyl chain of surfactant is on interesting behavior.
\end{abstract}

\section{1. 緒言}

界面活性剂は, 可溶化, 乳化, 分散等化粧品製造に際 して不可欠であり, かつ安全性, 安定性の面からその高 品質と少量化が要求されている。近年, 新規界面活性剂 が次々と合成されて括り，それらの界面活性剂の特質を 有効に利用するためには，その物性面での評価方法を確 立する必要がある。又, 界面活性剤はその系に用いられ る油との組合せによりその特性が大さく影響される。特 飞化粧品の場合には利用される油が, 化粧効果, 感触等 から 5 種類も多く性質も様々であり, 界面活性剤の選択 をする時には油との関係を充分考慮しなければならな い。我々はこの点から界面活性剤と油の組合せに基ついい ていくつかの化粧品的評価法を試み，それらによる特性 データを得たので報告したい。

系の中での界面活性剤の評価方法として, 転相温度方 式（PIT 法）は篠田らによって体系的研究が行なわれて 和り ${ }^{122)}$, 曇点法と共に界面活性剂評価法として有効であ る。また乳化力 (emulsifying power) と乳化安定性 (emulsion stability) 関する研究は, 古くから行なわ れている。乳化力については新規界面活性剂合成の際報 告されているが, 一般に少なく, 乳化安定性に関しては

ポーラ化成工業（株）研究所

横浜市神奈川区高島台 27-1

POLA Laboratories

27-1 Takashimadai, Kanagawa-ku Yokohama
理論的解明や促進テストが紹介されている3゙。これらの 研究を踏をえて, 代表的な構造の界面活性剂の代表的な 油に対しての乳化力とその安定性についても調べた。

\section{2. 界面活性剂の特性とその評価法}

化粧品的評価項目として物理化学特性を中心に Table -1のように分類し，位置づををした。

Tabl-1 Evaluation Terms.

\begin{tabular}{|c|c|c|c|}
\hline 特 & & 性 & 価＼cjkstart項 \\
\hline & 本 & 特 & $\begin{array}{l}\text { 表面張力, } \mathrm{CMC}, \mathrm{pH} \text {, 最点 } \\
\mathrm{EO} \text { 鎖長分布, 純度, 溶解性, } \\
\text { HLB, 化学安定性, 安全性, } \\
\text { 資化性 }\end{array}$ \\
\hline & 合 & 特 & $\begin{array}{l}\text { 可溶化 HLB. } \\
\text { 油飽和鳔点. } \\
\text { PIT. 乳化力. }\end{array}$ \\
\hline & 用 & 特 & 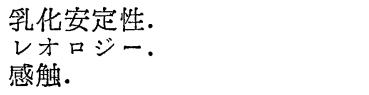 \\
\hline
\end{tabular}

評価特性は界面活性剂自身の性質を示す基本特性, 油 との組合せによる複合特性及び最も実際的で多くの特性 の関係する応用特性として考えた。今回はこれらのうち より実際的な評価法である油飽和晨点 (又は油性物質添 加系曇点), 転相温度 (PIT), 乳化力及び乳化安定性に ついて, 化粧品でしばしば用いられる界面活性剤と油と を組合せながら評価法としての実験条件, 測定条件, 表 
現条件等の条件確立を試みた。又, これらの実験から得 られた活性剤と油の組合せの特性データのらち, 各評価 項目ごとに 2,3 の知見を報告する。

\section{3. 実 験}

\section{$3-1$ 試 料}

界面活性㓮, 油は市販品及び当社合成品を用いた。乳 化系で界面活性剂構造の相異を示すため, 液体界面膜を もつ不飽和アルキル系 (オレイン酸誘導体) 界面活性剂 を中心に，必要に応じて直鎖飽和系（ステアリン酸誘導 体）や分岐飽和系 (イソステアリン酸誘導体) 界面活性 剂を使用した。
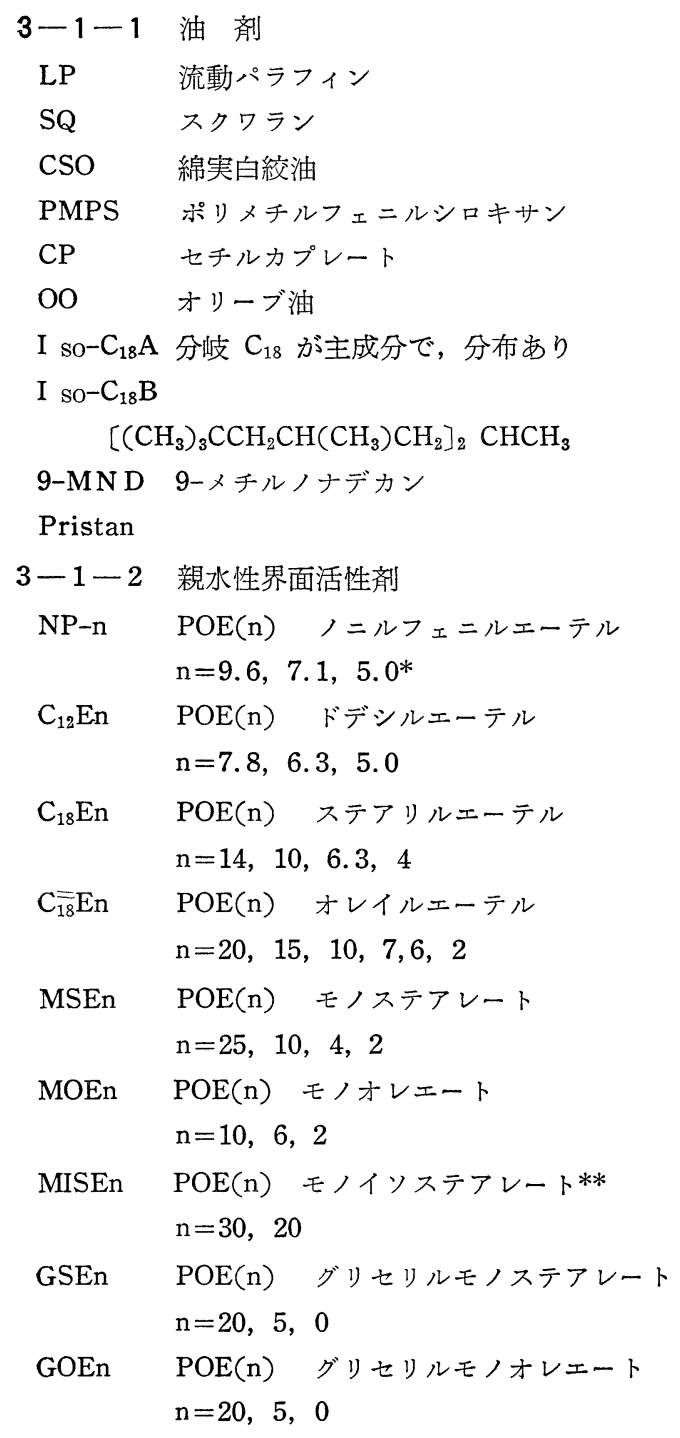

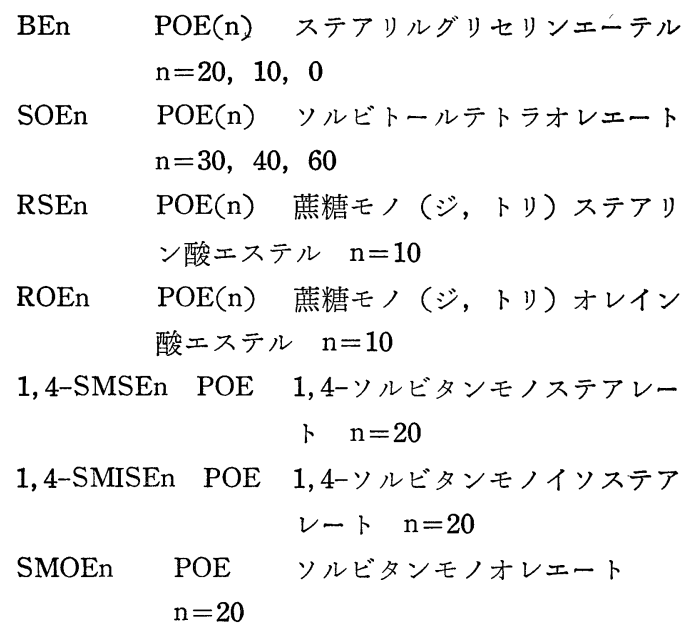

ROEn POE $(\mathrm{n})$ 菣糖モ) (ジ，トリ)オンイン 酸エステル $\mathrm{n}=10$

1,4-SMSEn POE 1,4-ソルビタンモノステアレー ト $\mathrm{n}=20$

1,4-SMISEn POE 1,4-ソルビタンモノイソステア SMOEn POE ソルビタンモノオレエート $\mathrm{n}=20$

*小数点以下が示されている付加モル数は実測モル数 であり，他はメーカー表示付加モル数。

**分岐脂肪酸は $\alpha$ 分岐であり，てのイソステアリン酸 は 2-heptyl undecanoic acid

3-1-3 親油性界面活性剂㧍よび極性物質

SMS ソルビタンモノステアレート

1.4-SMS 1.4-ソルビタンモノステアレート

SMO ソルビタンモノオレェート

1,4-SMIS 1,4-ソルビタンモノイソステアレート

MGS グリセリルモノステアレート

MGIS グリセリルモノイソステアレート

1,4-SME 1,4-ソルビタンモノ2-オクチルドデカネー r

1,4-SDE 1,4-ソルビタンジ2-オクチルドデカネート

1,4-STE 1,4-ソルビタントリ2-オクチルドデカネー r

SLMIS ソルビトールモノイソステアレート

$\mathrm{C}_{12} \mathrm{OH}$ 直鎖ドデシルアルコール

$\mathrm{n}-\mathrm{CmOOH}$ 直鎖飽和脂肪酸

iso- $\mathrm{CmOOH} \alpha$-分岐脂肪酸

$\mathrm{n}-\mathrm{CmOH}$ 直鎖飽和脂肪アルコール

iso- $\mathrm{CmOH} \beta$-分岐脂肪アルコール

\section{3-2 実験操作, 静置条件, 測定観察条件, 表現条件} $3-2-1$ 量点, 油飽和量点

界面活性剂の晋点は, 系の種々の添加物の影響（界面 活性剤との相互作用)を最も鋭敏かつ迅速に示す。アン プル又は密閉式試験管に界面活性剤, 水, 添加物等を封 入し, 界面活性剂等を完全に溶解させる。その後薷点以 上に加熱し，熱履歷を消して平衡状態で測定する。 


\section{$3-2-2$ PIT}

量点測定法と同じく, 界面活性剤, 油, 水等をアンプ ルに封入し，PIT 以上にあげ熱履歷をなくした後，十分 平衡に到達させ測定する。目による観察法が不可能な場 合は，色素法や電気伝導度法を併用した。

\section{$3-2-3$ 乳化力, 安定性}

乳化は界面活性剤を油相に入れておき，両相とも 80 ${ }^{\circ} \mathrm{C}$ 付近をで加熱し，水相を油相に添加させ反転させる。 攪拌しながら急冷し, 各種の条件下で放置し安定性を判 定する。又安定な系では界面活性鼡を低濃度にし, ホモ ゲナイザーで乳化した。

○反転乳化法の処方

$$
\left\{\begin{array}{lr}
\text { 油 } & 20 \% \\
\text { 界面活性剤 } & 5 \% \\
\text { 水 } & 75 \%
\end{array}\right.
$$

○ホモゲナイザー乳化法の処方

$$
\left\{\begin{array}{lr}
\text { 油 } & 20 \% \\
\text { 界面活性剂 } & 2 \% \\
\text { 水 } & 78 \%
\end{array}\right.
$$

○安定性放置条件

$20^{\circ} \mathrm{C}, 40^{\circ} \mathrm{C},-10^{\circ} \mathrm{C}$, Aging $\left(-5^{\circ} \mathrm{C} \sim 40^{\circ} \mathrm{C}\right)$

○測定条件

1 週間, 1 ケ月

○判 定 法

乳化力; 粒径, 粒度分布の顕微鏡権察 (乳化直後)。 乳化領域; 一定の粒径をもつ HLB 域の広さ。 乳化安定性; 経時による合一, 凝集, 排液の測定。

$$
\left(40^{\circ} \mathrm{C} 1\right. \text { 週間後) }
$$

\section{○表現条件}

Fig. -1 に示される様に HLB 軸の上段に乳化力下段 に安定性, 丸印で乳化実験值を表現して。例えば安定性 に执いて，斜線部で示される部分ば $40^{\circ} \mathrm{C}$ 及び室温 1 週間後油相分離なし，粒径 $1 \sim 2 \mu$, 排液量 $10 \%$ 以

$$
\text { Lower } \longrightarrow \text { H L B Higher }
$$

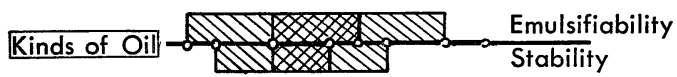

\section{Particle Size $<1 \mu$ \\ Particle Size $1 \sim 2 \mu$}

Fig. -1 The indication method of emulsifying power and emulsion stability
下クリーミングなしの条件を満たし，二重斜線は，油相 分離, 排液, クリーミングなしで, 粒径 $1 \mu$ 以下の条件 を満足する領域である。

\section{4. 結果と考察}

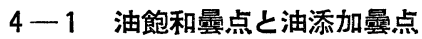

油飽和量点と PIT との相関性は, 篠田らによって報 告されている。Fig-1 より最大可溶化量が炭化水素同志 では分子量に反比例して堌加し，極性油では極めて大き い事が分る。

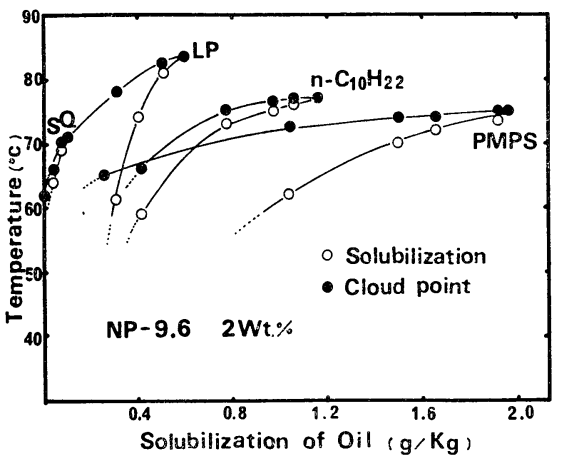

Fig-2 The solubilization curves of various oils 測定上の効率から, 単に油添加系の量点を利用して油の 差異を予想する事も可能である。

油がさらに極性をもった場合, 例えば MGS（モノグ リセリルステアレート) の様な極性物質（親油性界面活 性剤）では添加の影響は当然異なる。Fig-3では三成分 系の相図を示している。
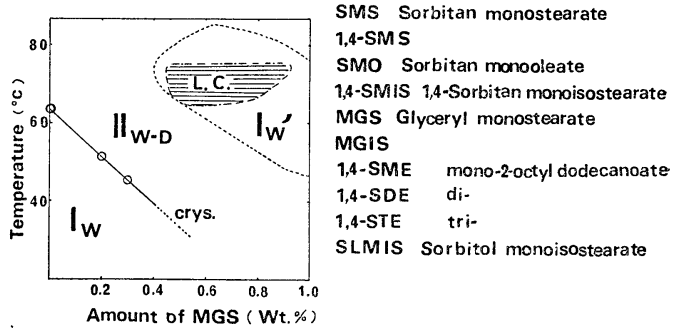

Fig-3 The phase diagram of surfactant-MGSwatar three components system.

極性物質の添加量と共に量点は直線的に下がり, 又高温 域に青白色の強いI相領域が存在する。さらに種々の親 油性界面活性剂の影響を Fig-4 に示す。

活性剤の曇点低下への影響は分岐脂肪酸モノェステル 誘導体〉直鎖脂肪酸（不飽和も含む）モノェステル誘導 


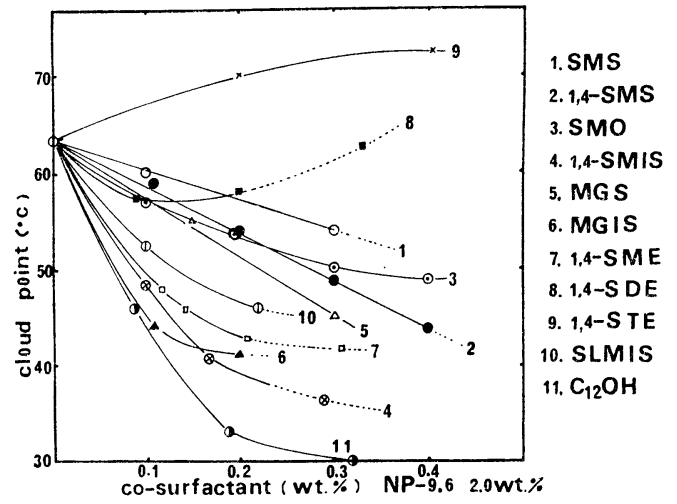

Fig-4 The effect of additives on the cloud point of surfactant.

体であり，ジェステル誘導体は少量では低下させるが， 增加と共に上昇傾问にある。又トリエステル誘導休では 通常の油と同じ挙動を示す。破線は系が青白色を是し殿 分離しにくくなる事を示すが, 分岐脂肪酸エステル系ほ ぞその傾问が滍い事が理解できる。

\section{$4-2$ PIT}

乳化系そのものの特性として PIT は重要である。间 族体に执いて分子量に比例てし PITが増す事が Fig. -5 に示される。

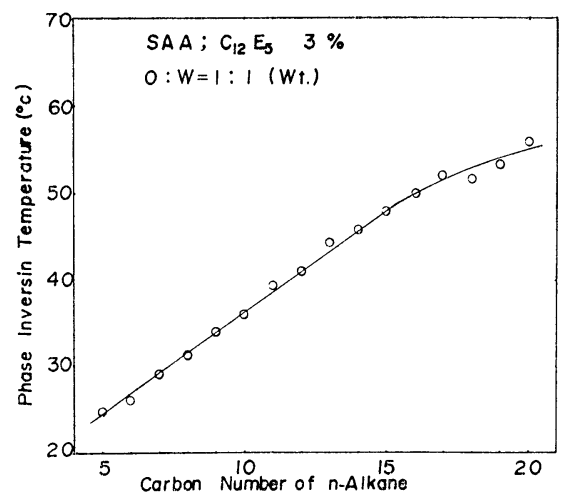

Fig-5 The effect of the chain length of n-alkane on the PITs.

淌級アルコールや脂肪酸がエマルジ:ンの界面に吸着 して PIT を下げる事が知られている。Fig-6 より，炭 䋕数 12〜18 迄の高級アルコールや脂肪酸を系に添加す ると, それぞれの系列に拈いて 1 分子当りの PIT 添加 度は, 炭素数に依存しない。すなわち脂肪酸ならば炭素 数によらず 1 分子当り同じ㗢さをするわけである。 同じ事は $\beta$-分岐アルコールと $\alpha$-分岐脂肪酸についても

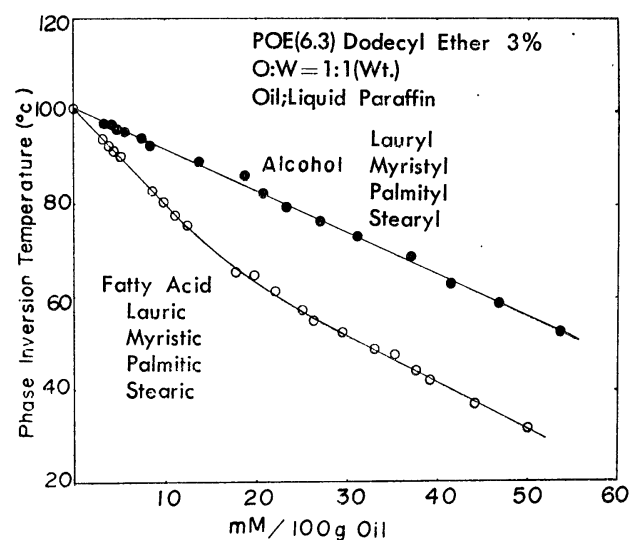

Fig-6 The effect of fatty alcohols and fatty acids on the PITs.

恐められる。炭素鎖長 $16 \sim 20$ の $\alpha$ - 分岐脂肪酸や $\beta$-分 岐アルコールの PIT への影響を直鎖系と比較したのが

Fig-7である。

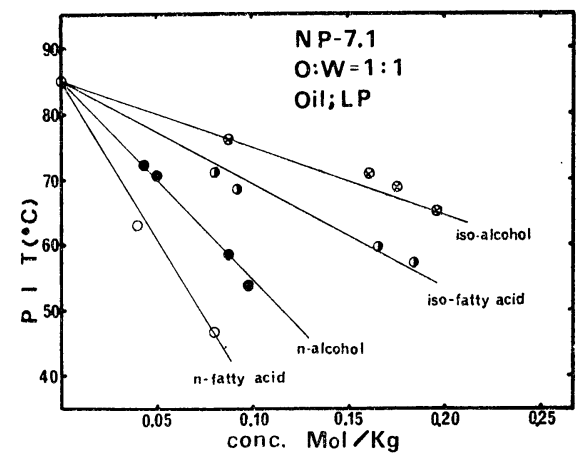

Fig-7 The effect of the hydrophobic groups of fatty alcohols (or fatty acids).

直鎖系は分肢系より脂肪酸, アルコール共 3 倍 PIT 低 下度が大きい。この様な PIT での相違は界面吸着力に 低存しており，アルキル基の分岐によって単に有効鎖長 が減少したのではなく，極性が大きく変化し油的挙動を とる為であろら。

\section{4-3 PIT 法による各種油, 親油性界面活性剂特性}

\section{効果}

物性面からの油の把握として, 炭素鎖長 18～20 のハイ ドロカーボンの特性值を比較したのが, Table-2である。 PIT, 油添加系曇点及び可溶化に要する最適副界面活性 剤量の特性中, 最も PIT が油間の相違学示している。 Iso- $\mathrm{C}_{18}$ の A, B 間の差は油への活性剤の溶解性と少量 の水を加えたときの溶解性の違いから予想される様に, PIT に示される。 
Tabl-2 The properties of various oils.

\begin{tabular}{|c|c|c|c|c|c|}
\hline \multirow{2}{*}{$\begin{array}{r}\text { Proper- } \\
\text { ties } \\
\begin{array}{c}\text { Hydro- } \\
\text { rcabon }\end{array}\end{array}$} & \multicolumn{2}{|c|}{ PIT $\left({ }^{\circ} \mathrm{C}\right)$} & \multirow{2}{*}{$\begin{array}{r}\mathrm{Cp}\left({ }^{\circ} \mathrm{C}\right) \\
\mathrm{NP}-9.6 \\
\text { Oil } 0.2 \%\end{array}$} & \multirow{2}{*}{$\left|\begin{array}{l}\text { Suitable } \\
\text { quantity } \\
\text { of } \\
\mathrm{n}-\mathrm{C}_{12} \mathrm{H}_{25} \\
\mathrm{OH} \\
\mathrm{Wt} . \%\end{array}\right|$} & \multirow{2}{*}{$\begin{array}{l}\text { Solubili- } \\
\text { ty of } \\
\text { NP-5. } 0\end{array}$} \\
\hline & NP-5.0 & NP-7.1 & & & \\
\hline 9-MND $\left(\mathrm{C}_{20}\right)$ & 40.5 & 86 & 74.0 & 1.75 & $\operatorname{In}(\operatorname{In})^{*}$ \\
\hline $\operatorname{Pristan}\left(\mathrm{C}_{19}\right)$ & 34.5 & 85 & 74.0 & 1.70 & $\operatorname{In}(\operatorname{In})^{*}$ \\
\hline iso- $\mathrm{C}_{18} \mathrm{~B}$ & $5>$ & 63 & 71.0 & 1.56 & In $(\mathrm{S}) *$ \\
\hline iso- $\mathrm{C}_{18} \mathrm{~A}$ & 20.5 & 76 & 71.0 & 1.55 & $\operatorname{In}(\operatorname{In}) *$ \\
\hline
\end{tabular}

( )* : with small quanty of wiater.

Tabl-3 The effect of the lipophilic surfactants on the PITs.

\begin{tabular}{|c|c|c|c|c|c|}
\hline \multirow[b]{2}{*}{$\mathrm{Co}-\mathrm{AA}$} & \multicolumn{3}{|c|}{ Solubility $\left(40^{\circ} \mathrm{C}\right)$} & \multicolumn{2}{|c|}{ PIT $\mathrm{LP} / \mathrm{H}_{2} \mathrm{O}=1 /$} \\
\hline & L P & $\begin{array}{c}\text { Olive } \\
\text { Oil }\end{array}$ & PMPS & $\begin{array}{c}\mathrm{NP}-7.1 \\
2.0 \% \\
\mathrm{Co}-\mathrm{SAA} \\
1.0 \%\end{array}$ & $\begin{array}{c}\mathrm{NP}-7.1 \\
5.0 \% \\
\mathrm{Co}-\mathrm{SAA} \\
2.5 \% / \mathrm{oil}\end{array}$ \\
\hline SMS & $\begin{array}{r}\text { In ; S } \\
\left(80^{\circ}\right) \\
\end{array}$ & $\begin{array}{c}\text { In ; S } \\
\left(80^{\circ}\right)\end{array}$ & $\begin{array}{c}\text { In ; S } \\
\left(80^{\circ}\right)\end{array}$ & $47\left({ }^{\circ} \mathrm{C}\right)$ & \\
\hline $1,4-\mathrm{SMS}$ & In & In & In & 50.5 & 66 \\
\hline SMO & $\mathrm{S}$ & $\mathrm{S}$ & $\mathrm{S}$ & 44 & \\
\hline $1,4-\mathrm{SMIS}$ & $\mathrm{S}$ & $\mathrm{S}$ & $\mathrm{S}$ & $9-25$ & $20-25$ \\
\hline 1,4-SMFS & $\mathrm{S}$ & S & $\mathrm{S}$ & $9-25$ & \\
\hline 1,4-SME & $\mathrm{S}$ & $\mathrm{S}$ & $\mathrm{S}$ & $9-25$ & \\
\hline 1,4-SDE & $\mathrm{S}$ & $\mathrm{S}$ & $\mathrm{S}$ & 58 & \\
\hline \multicolumn{6}{|l|}{ 1.4-STE } \\
\hline MGS & $\begin{array}{r}\text { In ; S } \\
\left(80^{\circ}\right) \\
\end{array}$ & $\begin{array}{r}\text { In ; S } \\
\left(80^{\circ}\right) \\
\end{array}$ & $\begin{array}{r}\text { In ; S } \\
\left(08^{\circ}\right) \\
\end{array}$ & 47 & 58 \\
\hline MGIS & $\mathrm{S}$ & $\mathrm{S}$ & $\mathrm{S}$ & $5>$ & $5-20$ \\
\hline SLMIS & $\mathrm{S}$ & $\mathrm{S}$ & $\mathrm{S}$ & $9-25$ & \\
\hline $\mathrm{C}_{12} \mathrm{OH}$ & $\mathrm{S}$ & $\mathrm{S}$ & $\mathrm{S}$ & 78 & \\
\hline $\mathrm{n}-\mathrm{C}_{18} \mathrm{OOH}$ & & & & & 63 \\
\hline $\mathrm{n}-\mathrm{C}_{18} \mathrm{OH}$ & & & & & 71.5 \\
\hline
\end{tabular}

又, 親油性界面活性剤；1,4-ソルビタンとグリセリン の直鎖及び分岐脂肪酸エステルについて, PIT への影響 を, Table-3. に示す。

図より明らかな様に先の量点への影響 (Fig. -4) と同一 の傾向を示す。PIT 低下の影響は，分岐脂肪酸モノエス テル誘導体 >直鎖脂肪酸モノエステル $=$ 直鎖脂肪酸 $>$ 分 岐脂肪酸であり, 分肢脂肪酸エステル誘導体系が直鎖脂
肪酸エステル誘導体系より著しくPIT を下げる。この 分岐脂肪酸モノエステル誘導体中の不純物，たとえば分 岐脂肪酸，1４４-ソルビタン，沓リエチレングリコール， ジェステル等が含まれているが，これらの PIT 低下要 因は小さい事から，この分岐脂肪酸モノエステル誘導体 の分子構造に基づ独自の PIT 低下力と界面活性を持 つと考えられる。従って乳化性に扣いても直鎖系とは異 なった特性が期待される。

\section{4-4 乳化力, 乳化安定性への活性剂と油との組合せ 効果}

数ある界面活性剂の中で, 今回は界面活性剤の構造因 子として親水部骨格構造, 連結部構造及び疎水部構造の 影響について油との組合せで検討した。即ち，代表的な 非イオン型親水性及び親油性界面活性剤; 脂肪酸エステ ル, アルキルエーテル, ソルビタンエステル, ソルビト 一ルエステル, 蔴糖エステル及びグリセライド等で，そ のアルキル基が直鎖飽和系, 不飽和系, 分岐飽和系をもつ ものを選んだ。そして同系列の活性剤の組合せで HLB を変化させ, 代表的な油の種類; スクワラン, 七チルカ プレート，オリ一ブ油及び PMPS に対する乳化力とそ の安定性を調べた。

$4-4-1$ 親水部骨格構造効果（グリセリン，ソルビ タン, 䓞糖, ソルビトール)

各構造ごとに特幑をあげると，

○ポリオキシェチレンソルビトールテトラオレエート系 では, 多種類の油に対して優れた乳化力, 乳化域の広さ 安定性を示す。

○ポリオキシェチレン蔴糖脂肪酸エステルでは, 炭化水 素類に対して強い乳化力を示すが, 極性油を乳化できな い。安定性がやや問題ある。

○ポリオキシェチレンアルキルェーテル系に扣いて, 炭 化水素, エステルに対してェチレンオキサイドが比較的 短い付加モル数で, 極めて強い乳化力を示すが, 長いも のと短い付加モル数の組合せでは, 他の活性剤系に比べ て弱い。安定性は良い。(Fig. -8 参照)

○ポリオキシェチレングリセリンのエステル，エーテル 型とも, 荻化水素, エステルに対して良好な乳化力, 安 定性资示吉。

4-4-2 連結部構造效果(エステル型とエーテル型) ポリオキシェチレン付加した脂肪酸エステルとアルキ ルエーテル又はポリオキシェチレン付加したグリセリン の脂肪酸エステル（グリセライド）とアルキルエーテル (グリセリルェーテル) の両者に执いて, 連結部の差に 
S.Q.

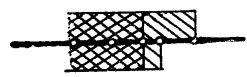

$C_{18}=E_{7} / C_{i 8}=E_{2}$

S.Q.
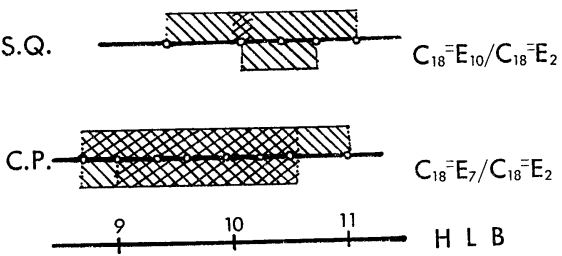

Fig-8 The emulsifiability of POE-alkylether type surfactants.

よる炭化水素類の乳化への影響は，エーテル型がエステ ル型より，乳化力，乳化安定性とも良好である。

4-4-3 疎水基構造効果（直鎖飽和型，不飽和型， 分岐不飽和型)

疎水基が直鎖（ステアリル基）と不飽和（オレイル基） の界面活性剂の炭化水素類の 乳化に対する影響を，ポ リオキシェチレン脂肪酸エステル系, ポリオキシェチレ ン蔴糖エステル系，ポリオキシエチレングリセリル脂肪 酸エステル系に㧤いて比較した。Fig. -9 は POE グリ セリン脂肪酸エステル型のスクワランに対する乳化性を 示す。

S.Q.

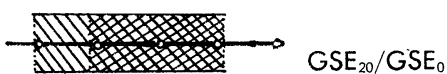

S.Q.

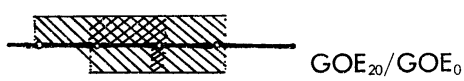

S.Q.

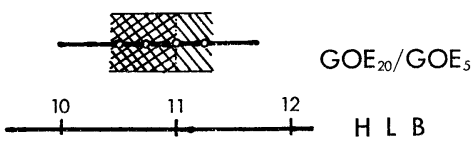

Fig-9 The effect of the hydrophobic groups of POE-glyceryl fatty acid ester type surfactants.

乳化安定性が 飽和脂肪酸 エステル型の方が優れてい る。Fig. -10 は上記 3 系統の蹯水基構造の乳化への影響 を季となものである。

不飽和系では耐温性に弱く，合一安定性が熹い傾问に ある。しかし，ポリオキシェチレンアルキルエーテル系 では, 両者の差は比較的小さい。一方, ポリオキシェチ レン脂肪酸エステル系での実験から，疎水基の分岐効果 は，乳化力では直鎖と同等であるが，乳化領域は拡大す る傾向にある。但し，この系は合一に対して不安定な為 に, 他の系列の親油性活性剤(スパーン類やモノグリ類)
Hydrophobic group

प्WIIID Hydrophilic group

(Polyoxyethylen chain)

Hydrophilic group

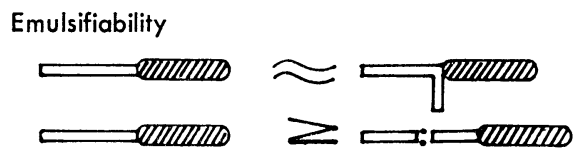

Width of emulsifiable range

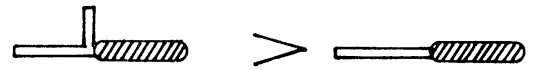

Emulsion stability

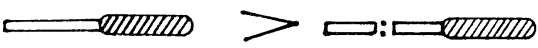

Fig. -10 The structural effect of hydrophobic groups on emulsification.

を選択する事によって，安定化が可能である。

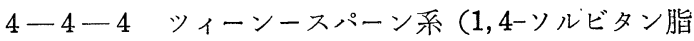
肪酸エステル系) の特性

この系は，他系列とかなり趣さを異にしている。

Fig.-11は，スクワランに対する乳化性の影響を，蹯 水基の組合せでもって比較した一例である。

S.Q.
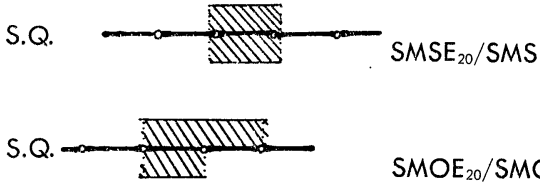

$\mathrm{SMOE}_{20} / \mathrm{SMO}$

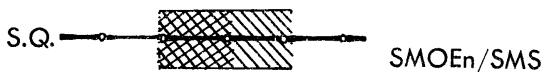

S.Q.

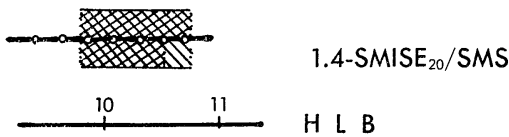

Fig. -11 The combination effect of the hydrophobic groups of sorbitan fatty acid.

POEソルビタンオレイン酸エステルーソルビタンステ アリン酸エステルの様な異系列の組合せが, 乳化力を増 している事が分る。この様な, 種々の組合せ効果, 油の 影響, さらに活性剤低濃度での超高温 ( $50^{\circ} \mathrm{C}$ 以上). 超 低温 $\left(-10^{\circ} \mathrm{C}\right)$ での挙動を Fig. -12 にまとめた。

これより, 乳化力, 乳化領域の広さは, 親水性一親油 
Emulsifiability and Width of emulsifiable range

facility of Emulsifi cation
Hydrophilic SAA Lipophilic SAA
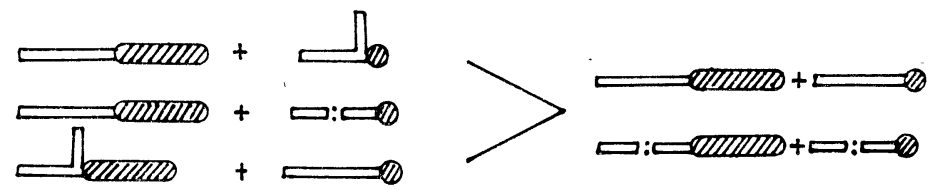

$\mathrm{CP}>\mathrm{SQ}$

$\mathrm{PMPS}>\mathrm{SQ}$

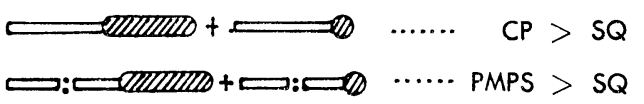

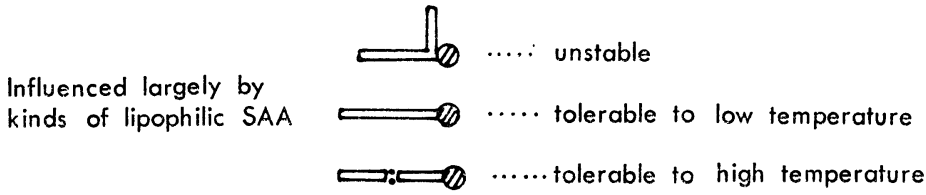

Fig.-12 The properties of Tween-Span system.

性界面活性剤の脂肪酸部の組合せに依存し, 㐤鎖一分岐, 直鎖一不飽和，或いは分岐一直鎖の様な，異なる脂肪酸 部の組合せが，直鎖同志又は不飽和同志の様な, 同系列 の組合せよりも乳化力が優れ，又乳化領域が広くなる。 しかし，分岐脂肪酸同志の 組合せでは，極めて悪かっ た。

種々の油に対する乳化のし易さは，直鎖脂肪酸同志の 組合せでは，七チルカプレート(エステル)〉スクワラ ン》PMPS の順であるが，不飽和同志の組合せでは， $\mathrm{PMPM}>$ スクワラン》セチルカプレートの順となり,

疎水基構造と油の間に深い関連がある。

乳化安定性は, 混合界面活性剤の中で親油性界面活性 剂への依存が大きく, 親油性界面活性剂が直鎖飽和系で は酎低温性，不飽和系では耐高温性に優れ，分岐系では 全般に不安定な傾向にある。

これらの乳化実験から得た結果の大部分は, 我々の日 常経験と一致している。しかしッウィーンースパーン系 の親油性界面活性剂が，画鎖飽和采では耐低温性，不飽 和系では耐高温性に優えているという結果は, 経験とは 矛盾している。分岐系を除けば, 他の界面活性剂系に比 較してッウィーンースパーン系の安定性, 特に奌温安定 性は優れている。これはツウィーンースパーン間, 或い いツウィーン一モノグリ分子間の会合, ラメシー相形成 や末端 $\mathrm{OH}$ 基の, 数の多さ等による安定化効果によるも
のと考えられる。

5. 総 括

非イオン型界面活性剤において純度の高いものを得る のは困難であり，ての特性から逆効果になる場合もあ る。可溶化系, 乳化系を利用しての界面活性剂評洒の分 野で, PIT は幅広い応用と知見を与えた。一方乳化力 安定性において, 一定条件下ながら女界面活性剂構造の 差異が明らかになった。注目したい事は，炭化水素鎖が 不飽和や分岐によって溶解性や界面活性が変化し, PIT や乳化特性に示される様な新しい特性をもつ事である。 アルキル基の分岐特性は, アルコール, エステル等多く の油剂や界面活性剂への利用が行なわれて扣り, 興味の ある分野と思われる。

終りに本研究の発表を許可されたポーラ研究所, 藤原 万亀雄所長に感謝します。

（1976年11月第 1 回 SCCJ 研劣討論会に执いて講演）

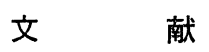

1）佐藤賢次：第 14 回油化学詩論会, 油化学研究発表 会, $59 ;$ 1977年洁化学投稿中

2）篠田耕三：日化，89，[5]435（1968）

3）光井武夫：色材，42，506（1969）

（昭和 52 年 8 月 9 日受理） 